\title{
PENGARUH TINGKAT PENDAPATAN, LAYANAN DAN KEPERCAYAAN TERHADAP MINAT PENGUSAHA WARUNG KOPI MEMBAYAR ZAKAT DI BAITUL MAAL KOTA LANGSA
}

\author{
Ade Fadillah Fw Pospos \\ Institut Agama Islam Negeri Langsa \\ Email : ade.pospos@iainlangsa.ac.id
}

\begin{abstract}
Abstrak,
Salah satu jenis bisnis yang memiliki potensi zakat terbesar di Aceh adalah kedai kopi. Namun minat pengusaha untuk membayar zakat di baitul maal masih kurang. Mereka lebih suka membayar zakat secara langsung. Meskipun dengan memanfaatkan layanan Baitul Maal, zakat akan didistribusikan secara adil dan merata dan dapat mengurangi kemiskinan di Kota Langsa. Penelitian ini bertujuan untuk mengetahui (1) mengetahui pengaruh tingkat pendapatan terhadap minat pengusaha warung kopi untuk membayar zakat di Baitul Maal, Kota Langsa; (2) untuk mengetahui pengaruh layanan terhadap minat pengusaha coffee shop untuk membayar zakat di Baitul Maal, Kota Langsa; (3) untuk mengetahui pengaruh tingkat kepercayaan terhadap minat pengusaha warung kopi untuk membayar zakat di Baitul Maal, Kota Langsa Penelitian ini menggunakan pendekatan kuantitatif. Populasi dalam penelitian ini adalah semua subjek penelitian, yaitu pengusaha warung kopi modern di Kota Langsa, yang berjumlah 45 orang. Metode pengumpulan data yang digunakan adalah kuesioner, wawancara dan dokumentasi. Uji prasyarat analisis yang dilakukan meliputi uji normalitas, uji linieritas dan uji multikolinieritas. Pengujian hipotesis menggunakan analisis regresi berganda. Hasil penelitian ini adalah (1) Pendapatan tidak mempengaruhi minat pengusaha warung kopi untuk membayar zakat di Baitul Maal, Kota Langsa dengan nilai signifikansi 0,756>0,05 (2) Layanan mempengaruhi minat pengusaha warung kopi yang membayar zakat di Baitul Maal, Kota Langsa dengan nilai signifikansi o,001 <0,05 (3) Kepercayaan tidak mempengaruhi minat pengusaha warung kopi untuk membayar zakat di Baitul Maal, Kota Langsa dengan nilai signifikansi 0,304>0,05>0,05
\end{abstract}

Kata Kunci : Penghasilan, Layanan, Kepercayaan, Minat Membayar Zakat, Baitul Mal

\begin{abstract}
,
One type of business that has the greatest potential for zakat in Aceh is a coffee shop. But the interest of entrepreneurs to pay zakat in baitul maal is still lacking. They prefer to pay their zakat directly. Even though by utilizing Baitul Maal services, zakat will be distributed fairly and evenly and can reduce poverty in Langsa City. This study aims to find out (1) to determine the effect of income level on the interest of coffee shop entrepreneurs to pay zakat in Baitul Maal, Langsa City; (2) to find out the effect of service on the interest of coffee shop entrepreneurs to pay zakat in Baitul Maal, Langsa City; (3) to determine the effect of the level of trust in the interest of coffee shop entrepreneurs to pay zakat in Baitul Maal, Langsa City This study uses a quantitative approach. The population in this study were all subjects of study, namely modern coffee shop entrepreneurs in Langsa City, amounting to 45 people. Data collection methods used were questionnaires, interviews and documentation. The analysis prerequisite tests carried out included the normality test, linearity test and multicollinearity test. Hypothesis testing uses multiple regression analysis. The results of this study are (1) Revenue does not affect the interest of coffee shop entrepreneurs to pay zakat in Baitul Maal, Langsa City with a significance value of 0.756>0.05 (2) Service affects the interest of coffee shop entrepreneurs paying zakat in Baitul Maal, Langsa City with a value significance of $0.001<0.05$ (3) Trust does not affect the interest of coffee shop entrepreneurs to pay zakat in Baitul Maal, Langsa City with a significance value of 0.304>0.05.
\end{abstract}

Keywords: Income, Service, Trust, Interest in Paying Zakat, Baitul Mal 


\section{PENDAHULUAN}

Salah satu permasalahan yang sering dihadapi oleh negara-negara berkembang adalah masalah ekonomi, termasuk negara Indonesia saat ini. Permasalahan ekonomi seringkali berdampak negatif terhadap kehidupan sosial masyarakat seperti, kemiskinan dan pengangguran yang sering kali menimbulkantindakan-tindakan kriminal. Oleh karena itu, untuk mengatasi problematika tersebut perlu adanya sebuah kebijakan untuk penanggulangan masalah kemiskinan. Sebagai negara yang penduduknya kurang lebih 90\% beragama Islam, maka tuntunan dan kiat Islam dalam mengantisipasi problematika kemiskinan umat menjadi penting untuk direalisasikan.

Tujuan zakat pada dasarnya adalah untuk membersihkan harta yangdimiliki oleh setiap orang yang sudahmemiliki nishab baik hasil perniagaan,pertanian, pertambangan, hasil laut,hasil ternak, harta temuan, emas dan perak serta hasil kerja (profesi) dimana masingmasing memiliki ketentuan dan perhitungan yang berbeda. Akan tetapi masih banyak orang yang belummenganggap dirinya wajib mengeluarkan zakat pada setiap tahunnya sesuai dengan perhitunganyang ditetapkan.Begitu pula dengan Infaq dan Shodaqoh, walaupun hal ini telahbanyak dikenal oleh semua muslim, tetapi hal ini belum banyakdipraktekan oleh sebagian masyarakat

Indonesia. Perbedaan zakat dengan infaq dan shodaqoh terdapat pada kewajiban dan syarat ketentuannya, hal inilah yang berakibat masih belum banyak kesadaran masyarakat untukmengeluarkan infaq dan shodaqoh.

Menurut Zainul Arifin (2000), di Indonesia terdapat lembaga semi-pemerintah yang berwenang untuk melakukan pengolahan dan pendistribusian zakat, yaitu Badan Amil Zakat dari tingkat nasional (BAZNAS) sampai tingkat daerah (BAZDA). Selain itu, ada juga lembaga non pemerintah yang bernama Lembaga Amil Zakat (LAZNAS/LAZDA). Sebuah penelitian yang diadakan oleh Pusat Bahasa dan Budaya UIN Syarif Hidayatullah dan Ford Fondation tahun 2003 menyebutkan jumlah filantropi umat Islam Indonesia mencapai 19,3 triliyun rupiah. Rinciannya dalam bentuk barang 51 triliyun rupiah dan uang 14,2 triliyun rupiah. Sepertiganya masih berasal dari zakat fitrah 6,2 triliyun rupiah dan sisanya zakat harta 13,1 triliyun rupiah.(Tabloid Jumat Sarana Informasi dan Komunikai Jamaah,2007). Dan untuk tataran dunia tahun 2010, menurut hasil penelitian Islamic Development Bank (IDB), potensi zakat dunia dalam setahun mencapai angka USD 600 milyar atau sekitar 600 triliyun rupiah. (Majalah INFOZ, 2010)

Menurut Kepala Baitul Mal Banda Aceh,potensi zakat terbesar yaitu berasal dari PNS dan Pengusaha. Dan salah satu jenis usaha yang memiliki potensi zakat paling besar di Aceh adalah warung kopi, seperti yang terlihat di Kota Langsa. Namun minat pengusaha untuk membayar zakat di baitul maal masih kurang.Mereka lebih memilih untuk membayarkan zakatnya secara langsung. Padahal dengan memanfaatkan jasa baitul maal, maka zakat yang 
akan didistribusikan secara adil dan merata dan dapat mengurangi kemiskinan di Kota Langsa.

Beberapa faktor yang kemungkinan menjadi penyebab yaitu pertama : kesadaran masyarakat untuk berzakat masih rendah. Kedua : pemahaman masyarakat tentang zakat khususnya zakat tentang maal dan zakat profesi yang masih kurang. Ketiga : rendahnya kepercayaan masyarakat kepada lembaga pengelola zakat, yang menyebabkan masyarakat enggan membayar zakat ke lembaga baitul maal. Keempat : ketidakmauan membayar zakat. Kelima : program penyaluran zakat saat ini dilakukan secara sporadis, incidental, dan sendirisendiri tanpa adanya perencanaan yang menyeluruh dan koordinasi antara lembaga pengelola zakat. Akibatnya sering terjadi tumpangtindih baik dari sisi mustahik penerima maupun program penyalurannya.

Berdasarkan latar belakang masalah di atas, maka rumusan permasalahan penelitian ini adalah bagaimana pengaruh tingkat pendapatanterhadap minat pengusaha warung kopi membayar zakat di Baitul Maal Kota Langsa, bagaimana pengaruh layananterhadap minat pengusaha warung kopi membayar zakat di Baitul Maal Kota Langsa dan bagaimana pengaruh kepercayaan terhadap minat pengusaha warung kopi membayar zakat di Baitul Maal Kota Langsa. Tujuan dari penelitian ini adalah untuk mengetahui pengaruh tingkat pendapatanterhadap minat pengusaha warung kopi membayar zakat di Baitul Maal Kota Langsa, untuk mengetahui pengaruh pelayananterhadap minat pengusaha warung kopi membayar zakat di Baitul Maal Kota Langsa dan untuk mengetahui pengaruh tingkat kepercayaanterhadap minat pengusaha warung kopi membayar zakat di Baitul Maal Kota Langsa.

\section{TINJAUAN TEORITIK}

Pendapatan (X1) adalah sebagai arus masuk atau kenaikan-kenaikan lainnya dari nilai harta suatu satuan usaha atau penghentian hutang- hutangnya atau kombinasi dari keduanya dalam suatu periode akibat dari penyerahan atau produksi barang-barang, penyerahan jasajasa, atau pelaksanaan aktivitas-aktivitas lainnya yang membentuk operasi-operasi utama atau sentral yang berlanjut terus dari satuan usaha tersebut.(Stice, Skousen, 2004, 230)

Pelayanan (X2) adalah adalah aktivitas atau hasil yang dapat ditawarkan oleh sebuah lembaga kepada pihak lain yang biasanya tidak kasat mata, dan hasilnya tidak dapat dimiliki oleh pihak lain tersebut. (Kotler,1994) Hadipranata (1980) berpendapat bahwa, pelayanan adalah aktivitas tambahan di luar tugas pokok (job description) yang diberikan kepada konsumen-pelanggan, nasabah, dan sebagainya-serta dirasakan baik sebagai penghargaan maupun penghormatan. 
Kepercayaan ( $\left.\mathrm{X}_{3}\right)$ adalah kemauan seseorang untuk bertumpu pada orang lain dimana kita memiliki keyakinan padanya. Menurut Rousseau et al (1998), kepercayaan adalah wilayah psikologis yang merupakan perhatian untuk menerima apa adanya berdasarkan harapan terhadap perilaku yang baik dari orang lain.

Minat (Y) adalah adalah kecenderungan yang agak menetap untuk merasa tertarik pada bidang-bidang tertentu dan merasa senang berkecimpung dalam bidang itu (W. S Winkel ,1983:38).

\section{Hipotesis}

Hipotesis yang dapat disusun dalam penelitian ini adalah sebagai berikut:

H1 : Terdapat pengaruh positif Pendapatan terhadap minat membayar zakat di Baitul Mal H2 : Terdapat pengaruh positif Layanan terhadap minat membayar zakat di Baitul Mal H3 : Terdapat pengaruh positif Kepercayaan terhadap minat membayar zakat di Baitul Mal $\mathrm{H}_{4}$ : Pendapatan, Layanan dan Kepercayan secara bersama-sama berpengaruh positif minat membayar zakat di Baitul Mal

\section{METODE PENELITIAN}

\section{Jenis Penelitian}

Jenis penelitian ini adalah penelitian lapangan (field ressearch) yakni pengamatan langsung terhadap obyek yang diteliti guna mendapatkan data yang relevan. Metode yang digunakan dalam penelitian ini adalah pendekatan kuantitatif.

\section{Sumber Data}

Data yang digunakan dalam penelitian ini adalah data primer dan data sekunder.Data primer diperoleh melalui penyebaran kuesioner melalui pengisian daftar pertanyaan yang telah dipersiapkan untuk penelitian ini dan observasi langsung ke lapangan dengan menggunakan teknik wawancara dengan responden. Sedangkan data sekunder diperoleh melalui dokumentasi dari berbagai informasi dari instansi terkait yang berhubungan dengan ruang lingkup penelitian, yaitu : Baitul Maal Kota Langsa serta hasil penelitian terdahulu dan literatur yang dianggap relevan mendukung penelitian ini.

\section{Populasi dan Sample}

Populasi dalam penelitian ini adalah keseluruhan subjek penelitian yaitu pengusaha warung kopi modern di Kota Langsa yang berjumlah 45 orang. Warung kopi modern yang dimaksudkan adalah warung kopi yang pengunjungnya di dominasi oleh anak muda, telah memiliki sarana wifi, dan menu yang disajikan tidak hanya kopi.

Sampel adalah sebagian populasi yang diteliti cara pengambilan sampel berpedoman pada Dr. Suharsimi Erikunto yang mengatakan bahwa "apabila subjeknya kurang dari 100, maka lebih baik diambil semua, dan jika jumlah subjeknya lebih besar dapat diambil antara $10 \%-15 \%$ atau $20 \%-25 \%$ atau lebih. 


\section{Teknik Analisis Data}

Data dalam penelitian ini diperoleh dengan data primer, sehingga teknik analisis data yang digunakan dimulai dengan melakukan uji validitas dan reliabilitas, uji validitas adalah suatu ukuran yang menunjukkan tingkat-tingkat kevalidan atau kesahihan sesuatu instrument. Tinggi rendahnya validitas instrument menunjukkan sejauh mana data yang terkumpultidak menyimpang dari gambaran tentang variable yang dimaksud (Imam Ghozali : 2001), dan uji reliabilitas adalah derajat ketepatan, ketelitian atau keakuratan yang ditunjukkan oleh instrument pengukuran (Husen Umar : 2001).

\section{Analisis Regresi}

Analisis regresi dapat dimanfaatkan untuk mengetahuibagaimana variabel dependen (kriteria) dapat diprediksikan melaluivariabel independen (prediktor).Dampak dari penggunaan analisis regresi dapat digunakan untuk memutuskan apakah naik atau menurunnya variabel dependen dapat dilakukan melalui menaikkan dan menurunkan keadaan variabel independen.

Untuk mengetahui besarnya pengaruh variabel bebas secara parsial maupun bersamasama terhadap variabel terikat dalam penelitian ini menggunakan analisis SPSS (Statistical Product AndService Solution), juga menggunakan analisis persamaan regresi berganda sebagai berikut:

$$
\mathbf{Y}=\mathbf{a}+\mathrm{b}_{1} \mathbf{X 1}_{1}+\mathrm{b}_{2} \mathrm{X} 2+\mathrm{b}_{3} \mathrm{X}_{3} \mathrm{e}
$$

Dimana:

$$
\begin{aligned}
& \mathrm{Y} \quad=\text { Minat } \\
& \mathrm{X} 1=\text { Pendapatan } \\
& \mathrm{X}_{2} \quad=\text { Layanan } \\
& \mathrm{X}_{3} \quad=\text { Kepercayaan } \\
& \text { a } \quad=\text { Nilai intercept (konstanta) } \\
& \text { b1- b2 - b3 = Koefisien arah regresi } \\
& \mathrm{e} \quad=\text { Variabel gangguan }
\end{aligned}
$$

\section{Uji Hipotesis}

Untuk menguji hipotesis, maka pengujian dilakukan dengan menggunakan koefisien Determinasi (R2) pada intinya mengukur seberapa jauh kemampuan model dalam menerangkan variasi variabel dependen. Nilai koefisien determinasi adalah antara nol dan satu. Uji hipotesis selanjutnya adalah uji parsial ( $t$ test) digunakan untuk mengetahui pengaruh masing-masing variabel independen terhadap variabel dependen. Model penelitian in adalah regresi berganda, maka uji hipotesis yang digunakan adalah uji simultan ( $f$ test ) digunakan untuk mengetahui apakah variabel independen secara bersama-sama atau simultan mempengaruhi variabel dependen. 


\section{HASIL DAN PEMBAHASAN}

Berikut hasil pengolahan data penelitian menggunakan spps versi 21.

\section{Uji Asumsi Klasik}

\section{Uji Normalitas}

Uji normalitas dengan grafik normal P-P Plot akan membentuk satu garis lurus diagonal kemudian plotting data akan dibandingkan dengan garis diagonal. Jika distribusi normal maka garis yang menggambarkan data sesungguhnya akan mengikuti garis diagonal.

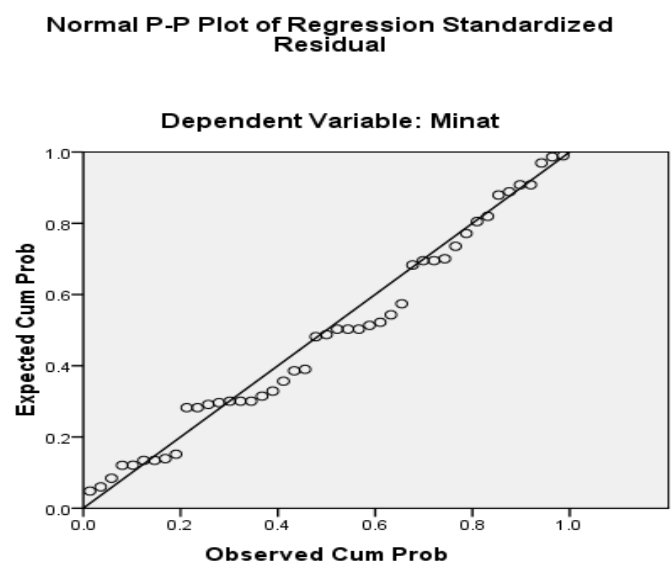

\section{Gambar 1. Uji Normalitas}

\section{Uji Autokolerasi}

Untuk penelitian ini, hasiluji autokorelasi adalah sebagai berikut :

\section{Tabel 1. Uji Autokorelasi}

Model Summary

\begin{tabular}{|c|c|c|c|c|c|c|c|c|c|c|}
\hline \multirow[b]{2}{*}{ Model } & \multirow[b]{2}{*}{$\mathrm{R}$} & \multirow[b]{2}{*}{ Rsguare } & \multirow[b]{2}{*}{$\begin{array}{l}\text { Adjusted } R \\
\text { Souare }\end{array}$} & \multirow[b]{2}{*}{$\begin{array}{l}\text { Stdd. Error of } \\
\text { the Estimate }\end{array}$} & \multicolumn{5}{|c|}{ Change statistics } & \multirow[b]{2}{*}{$\begin{array}{l}\text { Durbin- } \\
\text { Watson }\end{array}$} \\
\hline & & & & & $\begin{array}{l}\text { R Square } \\
\text { Change }\end{array}$ & F Change & difl & $d f_{2}$ & Sia. F Chance & \\
\hline 1 & $.518^{8}$ & .269 & .215 & 1.18895 & .269 & 5.019 & 3 & 41 & .005 & 2.471 \\
\hline
\end{tabular}

a. Predictors: (Constant), Kepercayaan, Layanan, Penghasilan

b. Dependent Variable: Minat

Nilai DW 2,471 lebih besar dari batas atas (du) yakni 1,6662. dan kurang dari (4-du) 4 $-1,6662=2,3338$ sehingga dapat disimpulkan bahwa tidak terdapat autokorelasi.

\section{Uji Multikolinearitas}

Pengujian ini bertujuan untuk mengetahui apakah setiap variabel saling berhubungan secara linear atau tidak. 


\section{Tabel 2. Uji Multikolinearitas}

Coefficients $^{\mathrm{a}}$

\begin{tabular}{|c|c|c|c|c|c|c|c|c|c|c|c|c|c|}
\hline \multirow[b]{2}{*}{ Mode_ } & & \multicolumn{2}{|c|}{ Unstandardized Coefficients } & \multirow{2}{*}{$\begin{array}{c}\text { Standardized } \\
\text { coeficients } \\
\text { Beta } \\
\end{array}$} & \multirow[b]{2}{*}{1} & \multirow[b]{2}{*}{$\mathrm{Sig}$} & \multicolumn{2}{|c|}{$95,0 \%$ Confidence Interval for $B$} & \multicolumn{3}{|c|}{ Correlations } & \multicolumn{2}{|c|}{ Collinearity Statistics } \\
\hline & & B & Std Error & & & & Lower Bound & Unper Bound & Zero-order & Partial & Pait & Tolerance & $\mathrm{V} \mathbb{E}$ \\
\hline 1 & (Constant) & 14.486 & 2.720 & & 5.326 & .000 & 8.993 & 19.979 & & & & & \\
\hline & Penghasilan & .032 & .101 & .044 & .313 & .756 & 1733 & .236 & .153 & .049 & .042 & .890 & 1.124 \\
\hline & Layanan & .308 & .088 & .492 & 3.493 & 001 & .130 & .486 & .514 & .479 & .466 & .899 & 1.112 \\
\hline & Kepercayaan & .030 & .099 & .044 & .304 & .763 & 1.170 & .230 & .206 & .047 & .041 & .840 & 1.190 \\
\hline
\end{tabular}

a. Dependent Variable: Minat

Hasil uji multikolinearitas (uji VIF) Pada tabel diatas menunjukkan bahwa nilai VIF kurang dari 10 dan tolerance lebih dari o.1, yang berarti bahwa model regresi tidak mengandung multikolinearitas.

\section{Uji Heterokedastisitas}

Uji heterokedastisitas berfungsi untuk menguji terjadinya perbedaan variance dari nilai residual pada suatu periode pengamatan ke periode pengamatan yang lain.

Scatterplot

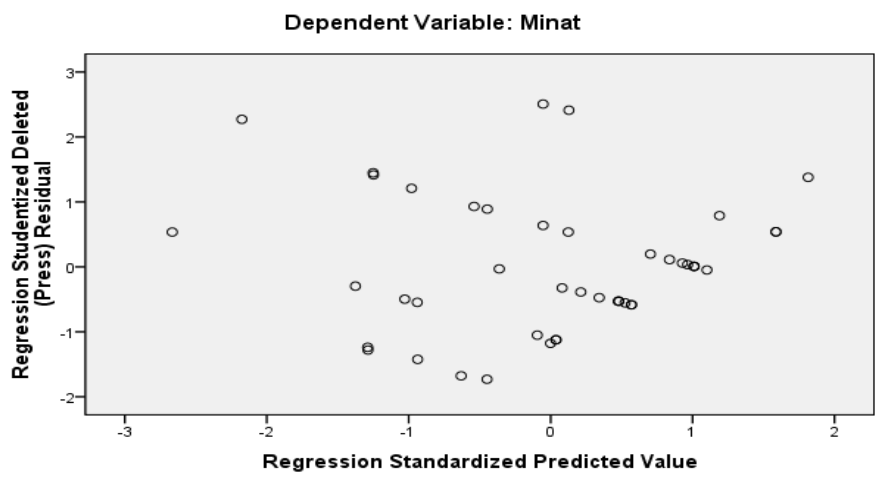

Gambar 2. Uji Heteroskedastisitas

Berdasarkan gambar di atas terlihat titik-titik pada grafik plot menyebar atau tidak membentuk pola tertentu. Artinya tidak terjadi heteroskedastisitas pada model regresi yang digunakan.

\section{Uji Reliabilitas}

Suatu kuesioner dikatakan reliabel atau handal jika jawaban seseorang terhadap pertanyaan dan pernyataan adalah konsisten atau stabil dari waktu ke waktu. SPSS memberikan fasilitas untuk mengukur reliabilitas dengan uji statistik Cronbach Alpha (ả).(Imam Ghozali : 2005)

Menggunakan sampel untuk uji kuesioner sebanyak 45 orang responden dengan signifikansi $5 \%$, dari sini di dapat nilai $\mathrm{df}=\mathrm{n}-2, \mathrm{df}=45-3=42(0,2876)$ 
PENGARUH TINGKAT PENDAPATAN, LAYANAN DAN KEPERCAYAAN TERHADAP MINAT PENGUSAHA WARUNG KOPI MEMBAYAR ZAKAT DI BAITUL MAAL KOTA LANGSA Ade Fadillah Fw Pospos

\section{Hasil Uji Reliabilitas Penghasilan}

\section{Tabel 3. Hasil Uji Penghasilan}

\begin{tabular}{|c|c|c|c|}
\hline & & $N$ & $\%$ \\
\hline \multirow[t]{3}{*}{ Cases } & Valid & 45 & 100.0 \\
\hline & Excluded ${ }^{a}$ & 0 & .0 \\
\hline & Total & 45 & 100.0 \\
\hline
\end{tabular}

a. Listwise deletion based on all

variables in the procedure.

\section{Reliability Statistics}

\begin{tabular}{|r|r|}
\hline $\begin{array}{c}\text { Cronbach's } \\
\text { Alpha }\end{array}$ & N of Items \\
\hline .473 & 5 \\
\hline
\end{tabular}

Item-Total Statistics

\begin{tabular}{|l|c|r|r|c|}
\hline & $\begin{array}{c}\text { Scale mean if } \\
\text { Item Deleted }\end{array}$ & $\begin{array}{c}\text { Scale } \\
\text { variance if } \\
\text { Item Deleted }\end{array}$ & $\begin{array}{c}\text { Corrected } \\
\text { item-Total } \\
\text { correlation }\end{array}$ & $\begin{array}{c}\text { Cronbach's } \\
\text { Alpha if Item } \\
\text { Deleted }\end{array}$ \\
\hline P1 & 18.0444 & 2.225 & .295 & .387 \\
P2 & 17.9333 & 2.427 & .253 & .419 \\
P3 & 18.1111 & 2.419 & .271 & .405 \\
P4 & 17.8889 & 3.010 & .118 & .493 \\
P5 & 17.8889 & 2.692 & .357 & .371 \\
\hline
\end{tabular}

\section{Hasil Uji Reliabilitas Layanan}

Tabel 4. Hasil Uji Layanan

\begin{tabular}{|c|c|c|c|}
\hline & & $N$ & 96 \\
\hline \multirow[t]{3}{*}{ Cases } & Valid & 45 & 100.0 \\
\hline & Excludeda & 0 & .0 \\
\hline & Total & 45 & 100.0 \\
\hline
\end{tabular}

a. Listwise deletion based on all

variables in the procedure.

Reliability Statistics

\begin{tabular}{|r|r|}
\hline $\begin{array}{c}\text { Cronbach's } \\
\text { Alpha }\end{array}$ & N of Items \\
\hline .556 & 5 \\
\hline
\end{tabular}

Item-Total Statistics

\begin{tabular}{|l|r|r|r|r|}
\hline & $\begin{array}{c}\text { Scale wean if } \\
\text { Item Deleted }\end{array}$ & $\begin{array}{c}\text { Scale } \\
\text { variance if } \\
\text { Item Deleted }\end{array}$ & $\begin{array}{c}\text { Corrected } \\
\text { Item-Total } \\
\text { Correlation }\end{array}$ & $\begin{array}{c}\text { Cronbach's } \\
\text { Alpha if Item } \\
\text { Deleted }\end{array}$ \\
\hline P6 & 16.8000 & 2.982 & .329 & .494 \\
P7 & 16.6667 & 2.909 & .423 & .433 \\
P8 & 16.7111 & 2.983 & .344 & .484 \\
P9 & 16.6444 & 3.598 & .203 & .559 \\
P10 & 16.7333 & 3.564 & .297 & .514 \\
\hline
\end{tabular}


Hasil Uji Reliabilitas Minat

Tabel 5. Hasil Uji Minat

\begin{tabular}{|c|c|c|c|}
\hline & & $\mathrm{N}$ & 96 \\
\hline \multirow[t]{3}{*}{ Cases } & valid & 45 & 100.0 \\
\hline & Excludeda & 0 & .0 \\
\hline & Total & 45 & 100.0 \\
\hline
\end{tabular}

a. Listwise deletion based on all

variables in the procedure.

Reliability Statistics

\begin{tabular}{|r|r|}
\hline $\begin{array}{c}\text { Cronbach's } \\
\text { Alpha }\end{array}$ & N of Items \\
\hline .373 & 5 \\
\hline
\end{tabular}

Item-Total Statistics

\begin{tabular}{|c|c|c|c|c|}
\hline & $\begin{array}{l}\text { Scale mean if } \\
\text { item Deleted }\end{array}$ & $\begin{array}{c}\text { Scale } \\
\text { Variance if } \\
\text { Item Deleted }\end{array}$ & $\begin{array}{l}\text { Corrected } \\
\text { Item-Tatal } \\
\text { correlation }\end{array}$ & $\begin{array}{c}\text { Cronbach's } \\
\text { Alpha if Item } \\
\text { Deleted }\end{array}$ \\
\hline P11 & 17.6222 & 1.377 & .079 & .408 \\
\hline P13 & 17.6889 & 1.310 & .139 & .361 \\
\hline$P_{14}$ & 17.7556 & 1.280 & .178 & .328 \\
\hline P15 & 17.8889 & 1.237 & .289 & .245 \\
\hline
\end{tabular}

\section{Hasil Uji Reliabilitas Kepercayaan}

Tabel 6. Hasil Uji kepercayaan

Case Processing Summary

\begin{tabular}{|ll|r|r|}
\hline & \multicolumn{1}{|c|}{ N } & \multicolumn{1}{c|}{$\%$} \\
\hline Cases & Valid & 45 & 100.0 \\
& Excludeda & 0 & .0 \\
& Total & 45 & 100.0 \\
\hline
\end{tabular}

a. Listwise deletion based on all

variables in the procedure.

\section{Reliability Statistics}

\begin{tabular}{|r|r|}
\hline $\begin{array}{c}\text { Cronbach's } \\
\text { Alpha }\end{array}$ & N of Items \\
\hline .448 & 5 \\
\hline
\end{tabular}

\begin{tabular}{|l|c|c|c|c|}
\hline \multicolumn{5}{|c|}{ Item-Total Statistics } \\
& $\begin{array}{c}\text { Scale wean if } \\
\text { Item Deleted }\end{array}$ & $\begin{array}{c}\text { Scale } \\
\text { variance if } \\
\text { Item Deleted }\end{array}$ & $\begin{array}{c}\text { Corrected } \\
\text { Item-Total } \\
\text { Correlation }\end{array}$ & $\begin{array}{c}\text { Cronbach's } \\
\text { Alpha if Item } \\
\text { Deleted }\end{array}$ \\
\hline P16 & 16.5333 & 2.573 & .235 & .397 \\
P17 & 16.2444 & 2.734 & .285 & .359 \\
P18 & 16.5778 & 2.522 & .312 & .333 \\
P19 & 16.4667 & 3.255 & .085 & .485 \\
P20 & 16.5778 & 2.886 & .268 & .375 \\
\hline
\end{tabular}




\section{Uji Validitasi}

Tabel 7. Hasil Uji Validitas Penghasilan

\begin{tabular}{|c|c|c|c|c|c|c|c|}
\hline & & $\mathrm{P} 1$ & $P 2$ & $P 3$ & $P 4$ & 85 & Penghasilan \\
\hline \multirow[t]{3}{*}{ P1 } & Pearson Correlation & 1 & .195 & $.295^{x}$ & .001 & 176 & $\frac{\text { Penghasilan }}{662^{\pi x}}$ \\
\hline & Sig. (2-tailed) & & .200 & .049 & .994 & .249 & .000 \\
\hline & $\mathrm{N}$ & 45 & 45 & 45 & 45 & 45 & 45 \\
\hline \multirow[t]{3}{*}{$\mathrm{P} 2$} & Pearson Correlation & .195 & 1 & .152 & -.050 & $.322^{*}$ & $.651^{x \times}$ \\
\hline & Sig. (2-tailed) & .200 & & .318 & .745 & .031 & .000 \\
\hline & $\mathrm{N}$ & 45 & 45 & 45 & 45 & 45 & 45 \\
\hline \multirow[t]{3}{*}{$\mathrm{P3}$} & Pearson Correlation & $.295^{x}$ & .152 & 1 & .103 & .048 & $.458^{\pi x}$ \\
\hline & Sig. (2-tailed) & .049 & 318 & & .500 & .753 & .002 \\
\hline & $\mathrm{N}$ & 45 & 45 & 45 & 45 & 45 & 45 \\
\hline \multirow[t]{3}{*}{ P4 } & Pearson Correlation & .001 & -.050 & .103 & 1 & $.333^{x}$ & .250 \\
\hline & Sig. (2-tailed) & .994 & .745 & .500 & & .025 & .098 \\
\hline & $\mathrm{N}$ & 45 & 45 & 45 & 45 & 45 & 45 \\
\hline \multirow[t]{3}{*}{ P5 } & Pearson Correlation & .176 & $.322^{\pi}$ & .048 & $.333^{*}$ & 1 & $.534^{\pi \times}$ \\
\hline & Sig. (2-tailed) & .249 & .031 & .753 & .025 & & .000 \\
\hline & $N$ & 45 & 45 & 45 & 45 & 45 & 45 \\
\hline \multirow[t]{3}{*}{ Penghasilan } & Pearson Correlation & $.662^{\mathrm{xa}}$ & $.651^{x \times}$ & $.458^{x x}$ & .250 & $.534^{\pi x}$ & 1 \\
\hline & Sig. (2-tailed) & .000 & .000 & .002 & .098 & .000 & \\
\hline & $\mathrm{N}$ & 45 & 45 & 45 & 45 & 45 & 45 \\
\hline
\end{tabular}

Tabel 8. Hasil Uji Validitas Layanan

\begin{tabular}{|c|c|c|c|c|c|c|c|}
\hline \multicolumn{8}{|c|}{ Correlations } \\
\hline & & $\mathrm{P6}$ & $\mathrm{P} 7$ & $\mathrm{P8}$ & $\mathrm{Pg}$ & P10 & Layanan \\
\hline \multirow{3}{*}{$\overline{P 6}$} & Pearson Correlation & 1 & .238 & .269 & .179 & .121 & $.602^{\mathrm{xx}}$ \\
\hline & Sig. (2-tailed) & & .115 & .074 & .240 & .428 & .000 \\
\hline & $N$ & 45 & 45 & 45 & 45 & 45 & 45 \\
\hline \multirow[t]{3}{*}{ P7 } & Pearson Correlation & .238 & 1 & $.327^{x}$ & .218 & .244 & $.664^{x x}$ \\
\hline & Sig. (2-tailed) & .115 & & .028 & .150 & .106 & .000 \\
\hline & $N$ & 45 & 45 & 45 & 45 & 45 & 45 \\
\hline \multirow[t]{3}{*}{$\mathrm{PB}$} & Pearson Correlation & .269 & $.327^{*}$ & 1 & .002 & .247 & $.669^{x=}$ \\
\hline & Sig. (2-tailed) & .074 & .028 & & .990 & 101 & .000 \\
\hline & $N$ & 45 & 45 & 45 & 45 & 45 & 45 \\
\hline \multirow[t]{3}{*}{$\mathrm{Pg}$} & Pearson Correlation & .179 & .218 & .002 & 1 & .143 & $.444^{\pi x}$ \\
\hline & Sig. (2-tailed) & .240 & .150 & .990 & & .347 & .002 \\
\hline & $N$ & 45 & 45 & 45 & 45 & 45 & 45 \\
\hline \multirow[t]{3}{*}{ P10 } & Pearson Correlation & .121 & .244 & .247 & .143 & 1 & $.547^{\pi x}$ \\
\hline & Sig. (2-tailed) & .428 & .106 & .101 & .347 & & .000 \\
\hline & $N$ & 45 & 45 & 45 & 45 & 45 & 45 \\
\hline \multirow[t]{3}{*}{ Layanan } & Pearson Correlation & $.602^{2 \pi}$ & $.664^{x x}$ & $.669^{x \pi}$ & $.444^{x \pi}$ & $.547^{x x}$ & 1 \\
\hline & Sig. (2-tailed) & .000 & .000 & .000 & .002 & .000 & \\
\hline & $N$ & 45 & 45 & 45 & 45 & 45 & 45 \\
\hline
\end{tabular}

*. Correlation is significant at the 0.01 level (2-tailed)

*. Correlation is significant at the 0.05 level (2-tailed)

Tabel 9. Hasil Uji Validitas Minat 


\begin{tabular}{|c|c|c|c|c|c|c|c|}
\hline \multicolumn{8}{|c|}{ Correlations } \\
\hline & & P11 & P12 & P13 & P14 & P15 & Minat \\
\hline \multirow[t]{3}{*}{ P11 } & Pearson Correlation & 1 & .024 & .161 & -.055 & .060 & $.338^{x}$ \\
\hline & Sig. (2-tailed) & & .877 & .292 & .722 & .693 & .023 \\
\hline & $N$ & 45 & 45 & 45 & 45 & 45 & 45 \\
\hline \multirow[t]{3}{*}{ P12 } & Pearson Correlation & .024 & 1 & .065 & .200 & $.315^{x}$ & $.524^{x x}$ \\
\hline & Sig. (2-tailed) & .877 & & .670 & .189 & .035 & .000 \\
\hline & $N$ & 45 & 45 & 45 & 45 & 45 & 45 \\
\hline \multirow[t]{3}{*}{ P13 } & Pearson Correlation & .161 & .065 & 1 & .055 & .040 & $.535^{x \pi}$ \\
\hline & Sig. (2-tailed) & .292 & .670 & & .722 & .793 & .000 \\
\hline & $N$ & 45 & 45 & 45 & 45 & 45 & 45 \\
\hline \multirow[t]{3}{*}{ P14 } & Pearson Correlation & -.055 & .200 & .055 & 1 & .226 & $.574^{\pi x}$ \\
\hline & Sig. (2-tailed) & .722 & .189 & .722 & & .136 & .000 \\
\hline & $N$ & 45 & 45 & 45 & 45 & 45 & 45 \\
\hline \multirow[t]{3}{*}{ P15 } & Pearson Correlation & .060 & $.315^{x}$ & .040 & .226 & 1 & $.550^{x x}$ \\
\hline & Sig. (2-tailed) & .693 & .035 & .793 & .136 & & .000 \\
\hline & $\mathrm{N}$ & 45 & 45 & 45 & 45 & 45 & 45 \\
\hline \multirow[t]{3}{*}{ Minat } & Pearson Correlation & $.338^{x}$ & $.524^{\pi x}$ & $.535^{x \pi}$ & $.574^{x \pi}$ & $.550^{x \pi}$ & 1 \\
\hline & Sig. (2-tailed) & .023 & .000 & .000 & .000 & .000 & \\
\hline & $N$ & 45 & 45 & 45 & 45 & 45 & 45 \\
\hline
\end{tabular}

*. Correlation is significant at the 0.05 level (2-tailed).

*. Correlation is significant at the 0.01 level (2-tailed)

Tabel 10. Hasil Uji Validitas Kepercayaan

\begin{tabular}{|c|c|c|c|c|c|c|c|}
\hline \multicolumn{8}{|c|}{ Correlations } \\
\hline & & P16 & P17 & P18 & P19 & P20 & Kepercayaan \\
\hline \multirow[t]{3}{*}{ P16 } & Pearson Correlation & 1 & .121 & $.333^{x}$ & .117 & -.048 & $.639^{x x}$ \\
\hline & Sig. (2-tailed) & & .427 & .025 & .445 & .753 & .000 \\
\hline & $N$ & 45 & 45 & 45 & 45 & 45 & 45 \\
\hline \multirow[t]{3}{*}{ P17 } & Pearson Correlation & .121 & 1 & .117 & .153 & $.304^{\pi}$ & $.575^{x \times x}$ \\
\hline & Sig. (2-tailed) & .427 & & .442 & .314 & .042 & .000 \\
\hline & $\mathbf{N}$ & 45 & 45 & 45 & 45 & 45 & 45 \\
\hline \multirow[t]{3}{*}{ P18 } & Pearson Correlation & $.333^{x}$ & .117 & 1 & -.103 & $.339^{x}$ & $.600^{x x}$ \\
\hline & Sig. (2-tailed) & .025 & .442 & & .501 & .023 & .000 \\
\hline & $\mathbf{N}$ & 45 & 45 & 45 & 45 & 45 & 45 \\
\hline \multirow[t]{3}{*}{ P19 } & Pearson Correlation & .117 & .153 & -.103 & 1 & .051 & $.384^{\pi x}$ \\
\hline & Sig. (2-tailed) & .445 & .314 & .501 & & .741 & .009 \\
\hline & $N$ & 45 & 45 & 45 & 45 & 45 & 45 \\
\hline \multirow[t]{3}{*}{$\mathrm{P} 20$} & Pearson Correlation & -.048 & $.304^{\pi}$ & $.339^{x}$ & .051 & 1 & $487^{\pi x}$ \\
\hline & Sig. (2-tailed) & .753 & .042 & .023 & .741 & & .001 \\
\hline & $N$ & 45 & 45 & 45 & 45 & 45 & 45 \\
\hline \multirow[t]{3}{*}{ Kepercayaan } & Pearson Correlation & $.639^{x x}$ & $.575^{x x}$ & $.600^{x \pi}$ & $.384^{x \pi}$ & $.487^{x \times}$ & 1 \\
\hline & Sig. (2-tailed) & .000 & .000 & .000 & .009 & .001 & \\
\hline & $N$ & 45 & 45 & 45 & 45 & 45 & 45 \\
\hline
\end{tabular}

*. Correlation is significant at the 0.05 level (2-tailed)

*. Correlation is significant at the 0.01 level (2-tailed)

\section{Analisis Regresi Berganda}

Tabel 11. Hasil Regresi

Coefficients $^{\mathbf{a}}$

\begin{tabular}{|c|c|c|c|c|c|c|}
\hline & & \multicolumn{2}{|c|}{$\begin{array}{l}\text { Unstandardized } \\
\text { Coefficients }\end{array}$} & $\begin{array}{l}\text { Standardized } \\
\text { Coefficients }\end{array}$ & \multirow[b]{2}{*}{$\mathrm{t}$} & \multirow[b]{2}{*}{ Sig. } \\
\hline \multicolumn{2}{|c|}{ Model } & B & Std. Error & Beta & & \\
\hline 1 & (Constant) & 14.486 & 2.720 & & $5 \cdot 326$ & .000 \\
\hline & Penghasilan & .032 & .101 & .044 & .313 & .756 \\
\hline & Layanan & .308 & .088 & .492 & 3.493 & .001 \\
\hline & Kepercayaan & .030 & .099 & .044 & .304 & .763 \\
\hline
\end{tabular}

a. Dependent Variable: Minat 
Dari data diatas, maka model persamaan regresinya adalah:

$$
\mathbf{Y}=14,486+0,32 X 1+0,308 X 2+0,030 X_{3}
$$

Persamaan tersebut bermakna, jika penghasilan meningkat maka akan meningkatkan minat membayar zakat sebesar 0,032, selanjutnya jika layanan ditingkatkan maka akan meningkatkan minat membayar zakat sebesar 0,308, dan jika kepercayaan meningkat akan meningkatkan minat membayar zakat sebesar 0,030.

\section{Uji Hipotesis}

\section{Uji Model R²}

Koefisien Determinasi $\left(\mathrm{R}^{2}\right)$ pada intinya mengukur seberapa jauh kemampuan model dalam menerangkan variasi variabel dependen. Koefisien determinasi dalam penelitian ini menggunakan nilai $R^{2}$. Hasil uji $R^{2}$ dapat dilihat pada dibawah ini:

\section{Tabel 12. Hasil R2}

Model Summary

\begin{tabular}{|l|r|r|r|r|}
\hline Model & \multicolumn{1}{|c|}{$\mathrm{R}$} & R Square & $\begin{array}{c}\text { Adjusted R } \\
\text { Square }\end{array}$ & $\begin{array}{r}\text { Std. Error of } \\
\text { the Estimate }\end{array}$ \\
\hline 1 & $.518^{\mathrm{a}}$ & .269 & .215 & 1.18895 \\
\hline
\end{tabular}

Data diatas menunjukkan nilai Adjusted R-Square sebesar 0,215, hal ini berarti bahwa 21,5 \% nilai variasi minat membayar zakat ditentukan oleh variabel-variabel dalam model penelitian, dan sisanya 78,5 dipengaruhi oleh variabel lain diluar model.

\section{Uji F}

Pengujian hipotesis yang menyatakan adapengaruh secara simultan (penghasilan, layanan, kepercayaan terhadap minat membayar zakat) dapat dilihat dari hasil uji F. Kriteria pengujiannya apabila nilai p value $<0,05$, dapat disimpulkan bahwa Ho ditolak. 
Tabel 13. Hasil Uji F

ANOVA ${ }^{b}$

\begin{tabular}{|c|c|c|c|c|c|c|}
\hline \multicolumn{2}{|c|}{ Model } & $\begin{array}{l}\text { Sum of } \\
\text { Squares }\end{array}$ & $\mathrm{df}$ & Mean Square & $\mathrm{F}$ & Sig. \\
\hline \multirow[t]{3}{*}{1} & Regression & 21.286 & 3 & 7.095 & 5.019 & $.005^{\mathrm{a}}$ \\
\hline & Residual & 57.958 & 41 & 1.414 & & \\
\hline & Total & 79.244 & 44 & & & \\
\hline
\end{tabular}

a. Predictors: (Constant), Kepercayaan, Layanan, Penghasilan

b. Dependent Variable: Minat

Hasil uji $\mathrm{F}$ diperoleh $\mathrm{F}$ hitung $=5,019$ dengan nilai $\mathrm{p}$ value $=(0.000)(\mathrm{a})<0.05$ sehingga dapat disimpulkan bahwa hipotesis diterima,yang berarti tiada pengaruh secara simultan (keseluruhan) penghasilan, layanan, dan kepercayaan terhadap minat membayar zakat.

\section{Uji t}

Pengujian hipotesis yang menyatakan ada pengaruh secara parsial loyalitas, kepuasan, dan kepercayaan terhadap keputusan nasabah dapat dilihat dari hasil uji t.

Tabel 14. Hasil Uji t

\section{Coefficients $^{\mathbf{a}}$}

\begin{tabular}{|c|c|c|c|c|c|c|}
\hline & & \multicolumn{2}{|c|}{$\begin{array}{l}\text { Unstandardized } \\
\text { Coefficients }\end{array}$} & $\begin{array}{c}\text { Standardized } \\
\text { Coefficients }\end{array}$ & \multirow[b]{2}{*}{$\mathrm{T}$} & \multirow[b]{2}{*}{ Sig. } \\
\hline \multicolumn{2}{|c|}{ Model } & B & Std. Error & Beta & & \\
\hline 1 & (Constant) & 14.486 & 2.720 & & $5 \cdot 326$ & .000 \\
\hline & Penghasilan & .032 & .101 & .044 & .313 & .756 \\
\hline & Layanan & .308 & .088 & .492 & 3.493 & .001 \\
\hline & Kepercayaan & .030 & .099 & .044 & .304 & .763 \\
\hline
\end{tabular}

a. Dependent Variable: Minat

\section{KESIMPULAN}

Setelah melihat hasil penelitian yang telah dibahas mengenaipengaruh tingkat pendapatan, layanan dan kepercayaan terhadap minat pengusaha warung kopi membayar zakat di baitul maal kota langsa.maka dapat diambil kesimpulan bahwa variabel tingkat pendapatan (X1) dan tingkat kepercayaan (X3) tidak berpengaruh secara signifikan terhadap minat pengusaha warung kopi membayar zakat di Baitul Mal Kota Langsa sedangkan variabel 
tingkat layanan (X2) berpengaruh secara signifikan terhadap minat pengusaha warung kopi membayar zakat di Baitul Mal Kota Langsa.

\section{DAFTAR PUSTAKA}

Anang Arif Susanto. (2002). Zakat sebagai Kebijakan Alternatif Anti Kesenjangan dan Anti Kemiskinan. Jurnal Ekonomi Syariah dan Muamalah Vol.1 No.1.

An-Nabhani Taqiyuddin. (2000). Membangun Sistem Ekonomi Alternatif Perspektif Islam, (AnNidlam al-Iqtishadi fil Islam), alih bahasa Moh. Maghfur Wachid, Cet. V. Surabaya: Risalah Gusti.

Arief. (2008). Akuntansi dan Manajemen Zakat (Mengkomunikasikan Sikap Kesadaran dan Membangun Jaringan, Jakarta : Kencana.

ChapraM. Umer. (2001). Masa Depan Ilmu Ekonomi, Jakarta : Gema Insani Press.

Didin. (2007). Zakat dalam Perekonomian Modern, Jakarta : Gema Insani Pers.

Daud Muhamad Ali. (1988). Sistem Ekonomi Islam Zakat dan Wakaf. Jakarta: UI-Press.

Ghozali Imam. (2001). Aplikasi Analisis Multivariate dengan Progran SPSS, Semarang: Badan Penerbit Universitas Diponegoro.

KahfMonzer. (1999). The Performance of the institution of Zakah in Theory and Practice, The International Conference on Islamic Economics Towards the 21st Century, Kuala Lumpur - Malaysia, April.

Mannan, MA. (1997). Teori dan praktek Ekonomi Islam, Dana Bhakti wakaf, Seri Ekonomi Islam No. 02, Edisi Lisensi, Yogyakarta. 